\title{
SERRATUS ANTERIOR BLOCK FOR PAIN RELIEF IN MULTIPLE RIB FRACTURES - CASE REPORT (SERRATUS ANTERIOR BLOCK IN MULTIPLE RIB FRACTURES)
}

\author{
Nataša Ilić1 ${ }^{1}$ Radomir Ilić
}

\begin{abstract}
${ }^{1}$ Clinical center of Vojvodina, Emergency center, Department of anesthesiology and intensive care, Novi Sad, Serbia
${ }^{2}$ Clinical center of Vojvodina, Emergency center, Department of emergency surgery, Novi Sad, Serbia
\end{abstract}

\section{Sažetak}

Uvod: Trauma grudnog koša predstavlja najčešći uzrok višestrukih preloma rebara. Intenzivni, „mučni” bol prisutan kod višestrukih preloma rebara može da predisponira pojavu respiratorne slabosti i pneumonije. Torakalna epiduralna analgezija i torakalni paravertebralni blok su efektivne, ali invazivne tehnike za analgeziju kod pacijenata sa ovim tipom povrede. Seratus anterior plane blok pod kontrolom ultrazvuka je novija tehnika nižeg stepena invazivnosti, tehnički lakše izvodljiva, sa nižim stepenom rizika za nastanak komplikacija. Prikaz slučaja: U radu smo prikazali slučaj bolesnika starosti 34 godine sa grudnom traumom i serijskim prelomom rebara, prisutnim izrazitim bolom, refrakternim na multimodalnu intravensku analgeziju, kod koga je primenjen obostrani seratus anterior blok. Blok je izveden pod kontrolom ultrazvuka, dat je bolus od $20 \mathrm{ml} \mathrm{0,25 \%} \mathrm{levobupivakaina} \mathrm{sa} \mathrm{dodatkom}$ $4 \mathrm{mg}$ deksametazona, između mišića seratusa anteriora $i$ latissimus dorsi. Nakon toga su obostrano plasirani kateteri sa kontinuiranom infuzijom 0,0625\% levobupivakaina $10 \mathrm{ml} /$ 2-4 h. Intenzitet bola je određen prema numerčkoj skali bola (NRS) pre i posle davanja bloka. Nakon davanja bloka u roku od sat vremena intenzitet bola je snižen za 50\%, odnosno sa 10/10 pre davanja bola na 5/10 posle davanja bloka. Nakon startovanja kontinuirane infuzije, bol je bio 0-1/10, bez potrebe za dodatnom intravenskom analgezijom. Zaključak: Kod našeg pacijenta sa višestrukim prelomima rebara, seratus anterior plane blok je obezbedio efikasnu analgeziju i pokazao se kao alternativa torakalnom epiduralnom i paravertebralnom bloku.

Ključne reči: serratus anterior; regionalna anestezija; višestruki prelomi rebara; analgezija

\section{Sumarry}

Introduction: Chest trauma is the most common cause of multiple fractured ribs. Multiple rib fractures result in intensive pain and can be a cause of respiratory failure and pneumonia. Thoracic epidural and thoracic paravertebral blocks are effective but potentialy invasive techniques to relieve the pain in patients with multiple rib fractures. Ultrasound guided serratus anterior plane block is a relatively newer technique that is less invasive, easier to perform, with low risk of complications. Case report: 34 -year-old patient with chest trauma and multiple rib fractures suffering with intensive pain regardless of multimodal intravenous analgesia was given bilateral serratus anterior plane block. Under ultrasound guidance, a bolus dose of $20 \mathrm{ml} \mathrm{0.25 \%} \mathrm{levobupivacaine} \mathrm{and} 4 \mathrm{mg}$ of dexamethasone was injected in the space between the serratus anterior and latissimus dorsi muscles. Catheters were inserted and an infusion of $0.0625 \%$ levobupivacaine was given at $10 \mathrm{ml} / 2-4 \mathrm{hr}$. Pain scores were recorded with Numerical Rating Scale (NRS) before and after the block. Patient had pain relief following the block of 50\% with in an hour, as pain score before block was 10/10 NRS while after block was 5/10 NRS. After continuous infusion of local anesthetic pain score was 0-1/10. No additional doses of analgesics were required. Conclusion: In our patient serratus anterior plane block provided effective analgesia in patient with multiple rib fractures. The serratus anterior plane block can be an alternative to thoracic epidural and paravertebral blocks.

Key words: serratus anterior; regional anesthesia; multiple rib fractures; analgesia 


\section{Introduction}

$\mathrm{C}$ hest trauma is the most common cause of multiple fractured ribs1. Multiple rib fractures result in intensive pain and can be a cause of respiratory failure and pneumonia2. Adequate pain control continues to be a challenging problem for the physicians. Intravenous multimodal analgesia with opioids is the most frequently used analgesia technique in this type of injury1,2. Opioid use is associated with multiple side effects including the suppression of the cough reflex, respiratory depression, nausea and vomiting.

Regional anesthesia techniques is considered as a gold standard for analgesia when multiple rib fractures are present ${ }^{1,2}$. Thoracic epidural and thoracic paravertebral blocks are effective but invasive techniques to relieve the pain caused by multiple rib fractures ${ }^{2}$. It can be difficult to perform, time consuming and with certain risks and contraindications ${ }^{1,2}$. Ultrasound guided serratus anterior plane block (SAP) is a novel technique, first described by Blanco et al. in 2013. that provides analgesia for the thoracic wall by blocking the lateral cutaneous branches of intercostal nerves from T2T9 levels ${ }^{3}$. This technique is less invasive, easier to perform, with low risk of complications ${ }^{1,2,3}$. We present a case report of a patient with chest trauma and multiple rib fractures who had severe pain, refractory to intravenous multimodal analgesia.

\section{Case report}

A 34 years old male patient, American Society of Anesthesiologists (ASA) physical status grade III was admitted in the emergency department of Clinical center of Vojvodina with spine and chest trauma after fall from 4 meters height. On arrival he was conscious, oriented (Glasgow Coma Score (GCS) 15), without neurological deficits. He was also hemodynamically stable, respiratory sufficient, SpO2 97\% on room air. Blood results were normal (complete blood count ( CBC) ), electrolytes, aspartate aminotransferase (AST), alanine aminotransferase (ALT), creatinine, activated partial thromboplastin time (aPTT), partial thromboplastin time (PT). Radiological evaluation was obtained including chest computed tomography
(CT) based on our trauma protocol. CT scan showed extensive injuries of cervical spine (fractures of cervical vertebra C2, C3 and C7 without dislocation), thoracic spine (fractures of thoracic vertebra from TH3 to TH10 without dislocation) and multiple rib fractures from 1-6 on the left side and from $2-3$ on the right side. The patient had bilateral pneumothorax and left sided hemothorax, and lung contusions. The chest tubes were inserted bilaterally immediately after admission (thoracic drain 24 Fr).

The analgesia regimen included intravenous opioids (morphine $6 \mathrm{mg}$ every 6 hours IV), paracetamol ( 1 g every 6 hours IV) and metamizole (2.5 g every 12 hours IV). Pain remained severe, patient was agitated, hypertensive, tachycardic, and was not able to preform deep breathing and adequate cough. The respiratory function was deteriorating based on clinical and radiological changes.

Patient was intubated on the second day of admission and stayed on mechanical ventilation (AC/VC+, $\mathrm{FiO} 2$ 0.5) and continuous analgosedation for 4 days. On the sixth day of admission tracheostomy was performed due to a concern of prolonged mechanical ventilation and uncertainty how the patient would be weaned from mechanical ventilation. After tracheostomy sedation was left out, intravenous multimodal analgesia continued, and patient was awake on pressure support mode of mechanical ventilation, experiencing intensive pain and weaning from mechanical ventilation was very difficult.

Therefore, we decided to perform ultrasound guided bilateral serratus anterior plane block (SAP). Procedure and possible complications were explained to the patient, and his informed and written consent was obtained. The block was performed with a patient in supine position with standard electrocardiogram, pulse oximetry and blood pressure monitoring. Linear ultrasound probe (3-10 MHz, Mindray M5, Shenzhen, China ) was placed at mid-axillary line between the fourth and the fifth rib (Figure 1). A needle for peripheral nerve block (22 G, Stimuplex, B. Braun, Melsungen, Germany) was placed under direct ultrasound visualization between serratus anterior and latissimus dorsi muscles (Figure 2). After negative aspiration, a bolus dose of $20 \mathrm{ml} 0.25 \%$ levobupivacaine with $4 \mathrm{mg}$ of dexamethasone was injected. 
Figure 1: Positioning the patient and the probe while performing serratus anterior block

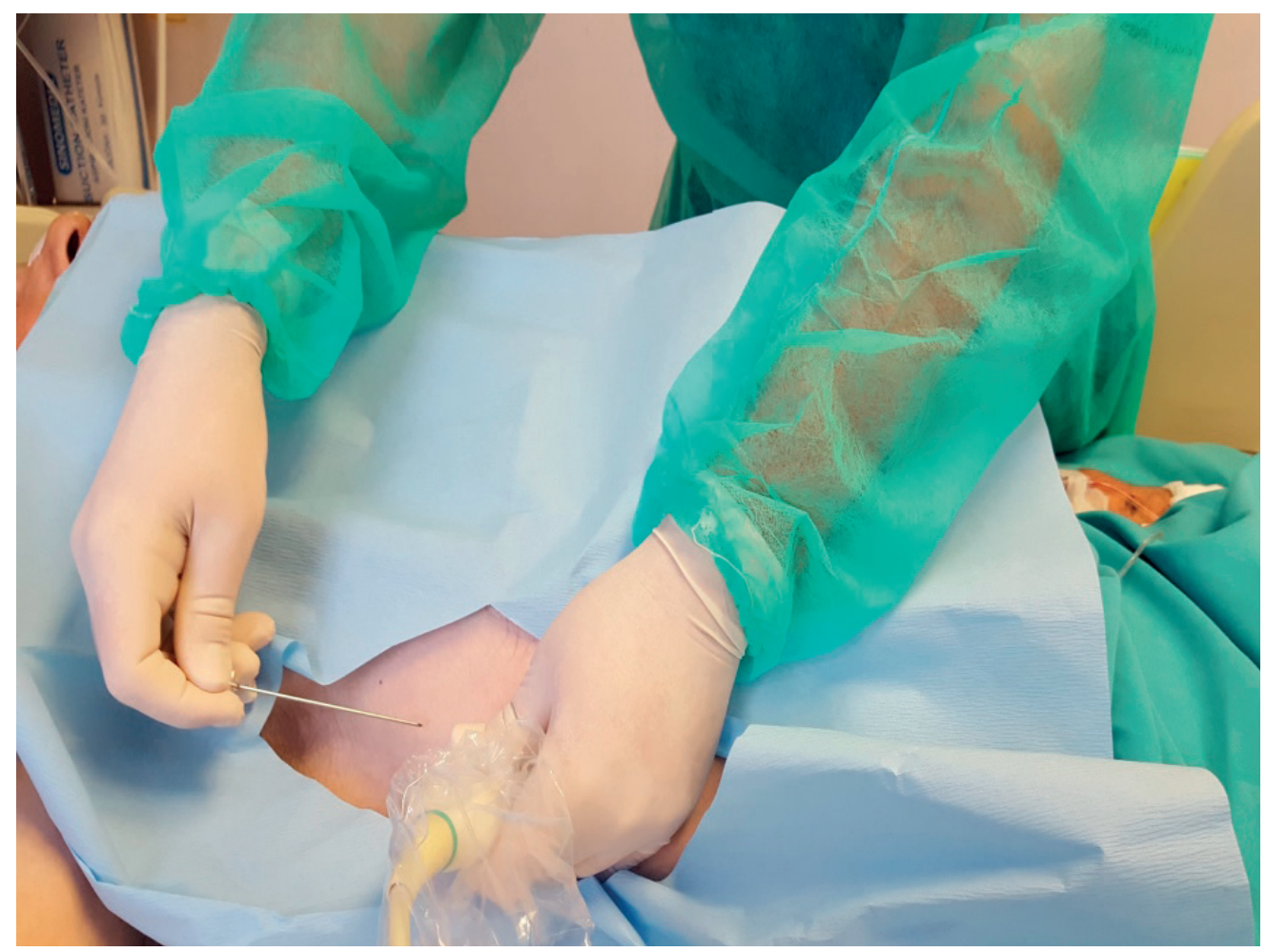

Figure 2: Sonoanatomy of Serratus Anterior Plane, where needle position and LA deposit shold be in the Serratus Anterior Plane block (arrow); SA - Serratus anterior muscle, LD - Latissimus dorsi, r4 - 4th rib, r5 - 5th rib

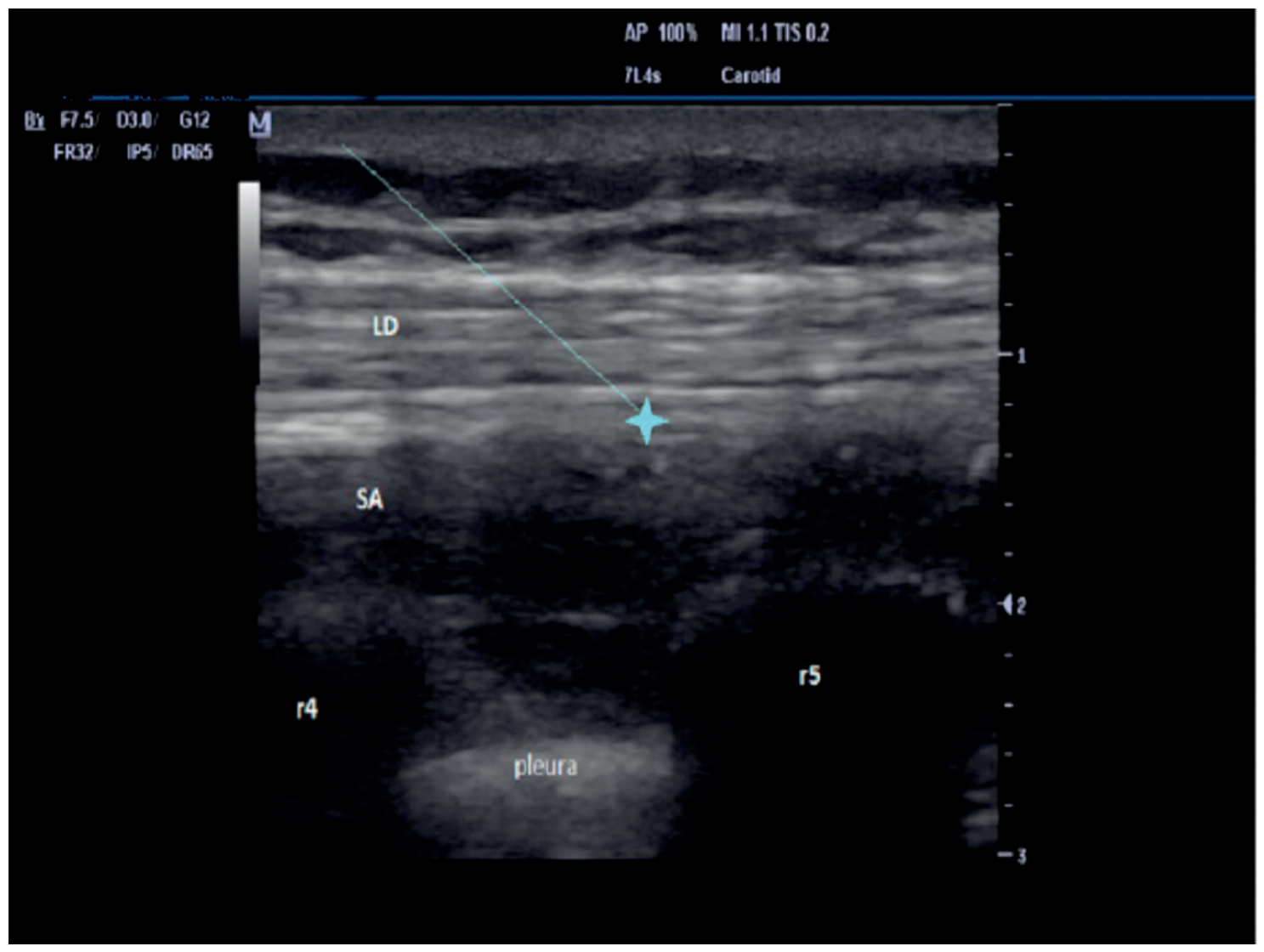


Afterwards peripheral nerve catheters were inserted and continuous infusion of $0.0625 \%$ levobupivacaine was started at rate $10 \mathrm{ml} / 2-4 \mathrm{hr}$. Patient also received intravenous opioids, acetaminophen and metamizole. Pain scores were recorded with Numerical Rating Scale (NRS) before and after the block performance, and 15 minutes following the block pain score on NRS was $5 / 10$ compared to pain score on NRS before block 10/10. During continuous infusion of local anesthetic pain score was $0-1 / 10$ during four days of follow up. Respiratory function improved, patient was calm, feeling more comfortable, cooperative during respiratory-physical rehabilitation. On the fifth day, patient was spontaneously breathing, respiratory function improvement was verified by arterial blood gas analyses. No additional doses of analgesics were required. Patient was discharged to the Clinic for thoracic surgery in Sremska Kamenica with pain intensity score on NRS of 2 .

\section{Discussion}

With this case report we intended to present benefits of SAP block and its role in the pain management after blunt thoracic trauma associated with rib fractures.

Managing acute rib fracture pain within the first two weeks of injury is critical, as acute pain intensity is predictive of chronic pain and disability ${ }^{4}$. Current gold standard for the management of pain in blunt thoracic trauma is the placement of a thoracic epidural catheter.

Traditional pain control options are associated with various side effects and complications. Many patients are elderly, with multiple comorbidities, and are on anticoagulant or antiplatelet therapy. The risk of hypotension due to the bilateral thoracic sympathectomy is also a concern, and it can be technically difficult to place an epidural catheter at thoracic level ${ }^{5}$. Our patient had accompanying injuries of cervical and thoracic spine that prevented him to be positioned for the performance of thoracic epidural catheter or paravertebral, erector spinae block, so they were technically unfeasible.

Development of novel approaches, such as serratus anterior block, is promising, as it carries fewer risks and contraindications; it is easy to perform under ultrasound guidance, and can provide adequate analgesia ${ }^{1,2,5}$. Moreover, it can be done in supine position. In our case, a multimodal intravenous analgesia was given initially, with inadequate pain control after several days of treatment, other regional techniques were unfeasible and that is why we decided to perform SAP block. This is a technique first described by Blanco et $\mathrm{al}^{3}$. In the original study, they administered $0.4 \mathrm{mg} / \mathrm{kg}$ of levobupivacaine $0.125 \%$ under ultrasound guidance to four volunteers, achieving analgesia from T2 to T9. Serratus anterior block evolved from the Pecs I and II blocks described by the same authors, and was intended to provide analgesia for patients undergoing surgery involving the thoracic wall, specifically for breast surgery ${ }^{1,3}$. It has since been described in the medical literature for other purposes, such as providing analgesia in thoracic trauma patients, particularly those with multiple rib fractures ${ }^{6}$.

Our case report and current literature clearly suggest that serratus anterior block is effective analgesia for multiple rib fractures. Enhancing analgesia with SAP may help improve pulmonary function, avoid adverse outcomes (secondary respiratory complications, prolonged mechanical ventilation) and reduce mortality, as opioid-sparing multimodal approach that integrates regional anesthesia ${ }^{7}$.

Serratus anterior plane block is currently subject of number of future clinical trials that have not been published yet ${ }^{8}$. Results of these studies will provide better understanding of the block, the ideal site for the placement of the catheter, the optimal concentration and dosage of the local anesthetic and to its efficiency compared with other analgesia methods.

\section{Conclusion}

Serratus anterior plane block can provide effective analgesia in patients with multiple rib fractures. It is our belief that SAP is an valuable option to be considered in difficult cases such is this, when supine positioning of the patient is of utmost importance. It can be an alternative to thoracic epidural and paravertebral blocks when they are contraindicated.

Disclore: Authors declare no conflicts of interest. 


\section{References:}

1. Jadon A. Serratus Anterior Plane Block for Pain Relief in Multiple Fractured Ribs (MFRs); Injection of Local Anaesthetic above the Serratus or below the Serratus? - A Case Report. J Anesth Crit Care 2017; 7(2):254-261.

2. Jadon A, Jain P. Serratus Anterior Plane Block-An Analgesic Technique for

Multiple Rib Fractures: A Case Series. American J Anesth Clin Res 2017; 3(1):1-4.

3. Blanco R, Parras T, McDonnell JG, Prats-Galino A. Serratus plane block: a

novel ultrasound-guided thoracic wall nerve block. Anaesthesia 2013; 68 (11):1107-1113.

4. May L, Hillermann C. \& Patil S. Rib fracture management. BJA Education 2016; 16(1):16-32.
5. Camacho FC, Segura-Grau E. Continuous serratus anterior plane block provides analgesia in multiple rib fractures: a case report. Rev Bras Anestesiol 2019; 69(1):87-90.

6. Kunhabdulla N, Agarwal A, Gaur A, et al. Serratus anteriorplane block for multiple rib fractures. Pain Phys 2014; 17(5):553-555.

7. Durant E, Dixon B, Luftig J, Mantuani D. \& Herring A. Ultrasound-guided serratus anterior plane block for ED rib fracture pain control. The American Journal of Emergency Medicine 2017; 35(1):193-197.

8. Khalil AE, Abdallah NM, Bashandy GM, Kaddah TA. Ultrasound-Guided Serratus Anterior Plane Block Versus Thoracic Epidural Analgesia for Thoracotomy Pain. Journal of Cardiothoracic and Vascular anesthesia 2017; 31(1):152-158. 